\title{
On the properties of VSO and VOS orders in Greek and Italian: a study on the syntax- information structure interface
}

Artemis Alexiadou

Institute of English Linguistics, University of Stuttgart, Germany

https://doi.org/10.36505/ExLing-2006/01/0001/000001

\begin{abstract}
This paper deals with word order variation that relates to patterns of information structure. The empirical focus of the paper is a comparison of Italian and Greek word order patterns. The paper will address, however, issues of word order typology in general. The main line of argumentation is one according to which syntax directly reflects information structure, and variation is explained on the basis different movement parameters.
\end{abstract}

\section{Introduction}

The patterns in (1-3) are all found in Greek and Italian, two pro-drop languages known to allow several word order permutations.

$$
\begin{array}{ll}
\text { 1. } & \mathrm{SV}(\mathrm{O}) \\
\text { 2. } & \mathrm{VS}(\mathrm{O}) \\
\text { 3. } & \text { VOS }
\end{array}
$$

In the recent literature a lot of attention has been devoted to the fact that these patterns reflect topic/focus relations. A possible description of the above patterns in terms of information structure is as follows:

1'. $\quad \operatorname{SV}(\mathrm{O})$ : subject is taken to be old information, i.e. it is a topic.

$2^{\prime}$. $\quad \mathrm{VS}(\mathrm{O})$ : in the unmarked case all information is new.

3'. VOS: the subject is new information.

The patterns in 2 and 3 can be further subdivided into a number of sub-types depending on intonation, which will be discussed here in detail.

The existence of these patterns raises three questions: (i) how are properties of information structure reflected in syntax? (ii) are all these orders and interpretations equally available in both languages? If not, what explains this variation? (iii) how are the VSO and VOS patterns related to e.g. Celtic VSO and Malagasy VOS? Questions (ii) and (iii) are important for the comparative syntax perspective. First, as we will see immediately, Italian is

ExLing 2006: Proceedings of 1st Tutorial and Research Workshop on Experimental Linguistics, 28-30 August 2006, Athens, Greece 
rather different from Greek. Second, intuitively there is a difference between e.g. Irish VSO and Malagasy VOS and the patterns discussed here. Importantly, in Greek and Italian the above are only some of a number of possible patterns and not the obligatory patterns, as is the case in the other languages and our syntactic theory should be able to explain this.

Here I focus on the VS(O) patterns and I briefly discuss VOS patterns.

\section{Patterns}

\section{Some terminology}

As the patterns to be discussed related to notions such as focus and topic, following Zubizarreta (1998: 10) and many others, I distinguish between contrastive focus and new information focus. There a number of criteria that can be used to tease them apart. Contrastive focus contrasts the subset of a set of alternatives with the complement subset. In this case, a background assertion is introduced by a statement. New information focus simply conveys new information. In this case, the background is introduced by whquestions.

\section{Different types of VS(O) patterns}

The following patterns can be distinguished:

(i) VS/VSO (with no particular intonation)

(ii) $\mathrm{V} \# \mathrm{~S}$ and $(\mathrm{cl}) \mathrm{VS} \# \mathrm{O}$ with comma intonation; in this case, the $\mathrm{S}$ and $\mathrm{O}$ are right-dislocated.

(iii) VS /VSO: in this case the subject bears contrastive focus and the object in the VSO case is de-accented but in situ (Zubizarreta 1998: 155f, see also Cardinaletti 2001).

(ii-iii) are equally found in Italian, and Greek, while (i) is restricted/impossible in Italian.
a. irthe o Janis
came John
b. irthe, o Janis
came John
c. agorase o Janis tin efimerida
bought John the newspaper
d. agorase o JANIS tin efimerida
bought John the newspaper
e. tin agorase o Janis, tin efimerida
it bought John, the newspaper

Greek 
(2)
a. ha parlato Gianni
has spoken John
b. ha parlato, Gianni
has spoken John
c. L'ha comprato Maria, il giornale
it bought Mary the newspaper
b. Ha comprato MARIA, il giornale
has bought Mary the journal

Italian

\section{The position of the subject in $\mathrm{VS}(\mathrm{O})$}

The position of the arguments in VS and VSO orders are taken to be low in the IP area, in particular within the vP, as it follows adverbs that mark the vP edge (Alexiadou \& Anagnostopoulou 1998, Belletti 1999).
a. ?Capirá bene Maria
will understand well Maria
b. *Capirá Maria bene
will understand Maria well

(4) an ehi idhi diavasi $i_{j}\left[{ }_{\text {vp }}\right.$ kala ${ }_{\text {vvp }}$ o Petros $t_{j}$ to mathima]] Greek if has already read well Peter the lesson If Peter has already read the lesson well

\section{VS: differences between Italian and Greek}

In Italian VS is marginal as an answer to the question 'What happened?':

(5) irthe o Janis

came John

(6) e'entrata Beatrice

is entered Beatrice

(7) \# e'impallidito Berlusconi

is turned pale Berlusconi

According to Benincá (1988) and Pinto (1997:21), the example in (7) is not felicitous under a wide focus interpretation, but acceptable under a narrow reading on the subject. Such an interpretation is in general possible with VS orders (see also Belletti 1999). For this reason, VS orders are felicitous answers to the question 'Who came?':

(8) irthe o Janis

came John

(9) e arrivato Gianni

is arrived John 
Thus we can conclude that Italian VS orders are generally characterized by new information focus on the subject. Only under special conditions can all information be considered new. Greek is not subject to these constraints.

Benincá (1988), Pinto (1997), Belletti (1999), Tortora (2001) and Cardinaletti (to appear) note that definite subjects can appear postverbally in Italian, if they satisfy the following two conditions:

$$
\text { the definite description identifies its referent in a }
$$
unique way

b. the definite description must bear new information (as the postverbal subject position is normally identified with focus)

Second, verbs that permit inversion with definite subjects in Italian differ in their lexical structure from those that do not permit inversion. In particular, the former contain a locative or temporal argument, which can be overtly or covertly realized, which is located in subject position. In particular, what occupies the preverbal position is a null locational goal argument of the unaccusative verb (Cardinaletti to appear). The aforementioned authors agree that when the locative remains implicit, it is interpreted deictically. Thus a sentence like (6) means that Beatrice arrived/entered here. That inversion is closely related to deixis in Italian is supported by the data in (11-12), from Pinto (1997: 130):

$$
\begin{aligned}
& \text { Da questo porto è partito Marco Polo } \\
& \text { from this harbour left Marco Polo } \\
& \text { *Dal porto è partita la nave } \\
& \text { from the harbour left the ship }
\end{aligned}
$$

(12) is ungrammatical. According to Pinto, the reason for this ungrammaticality is related to the difference between the demonstrative questo 'this' and the determiner $i l$ 'the'.

\section{$\mathbf{V \# S}$}

In this pattern the subject is already given information, separated by comma intonation. So as an answer to the question 'What did John do?', we can find the examples in (14) and (15), where especially in Greek the use of the overt subject is like an afterthought:

(14) efige, o Janis

left John

(15) ha parlato, Gianni

has spoken John 
Arguably the subject is in a right-dislocated position. According to Kayne (1994), Cardinaletti $(2001,2002)$, see also Georgiafendis (2001), in this case, the subject is generated in the complement of a functional projection whose specifier hosts the whole clause.

$$
\text { [[ efige }] \mathrm{X}^{\circ} \text { [o Janis ]] }
$$

\section{VSO}

In VSO orders in Greek, all information is new, and the subject is VP internal, as the pattern can function as an answer to the question 'what happened?'

$$
\begin{aligned}
& \text { molis espase o Janis tin kristalini lamba } \\
& \text { just broke the-John-NOM the crystal lamp } \\
& \text { 'John just broke the crystal lamp' }
\end{aligned}
$$

Italian disallows VSO but (data from Belletti 1999), but allows for VSPP and VSO orders when the subject is a pronoun:

a. Ha telefonato Maria al giornale has phoned Mary to the newspaper

b. $\quad *$ Ha telefonato Maria il giornale has caleld Mary the newspaper
a. Di quel cassetto ho io le chiavi of which drawer have I the keys
b. $\quad$ *Di quel cassetto ha Maria le chiavi of which drawer has Mary the keys

Why is VSPP possible but VSO impossible? Alexiadou \& Anagnostopoulou (2001) argued that intransitivity constraint on inverted orders of the type in (20); this is active in English and French, which do not permit inversion with transitive verbs.

(20) At Spell-Out the vP-VP should not contain more than one argument, at least one DP argument must check Case overtly

(20) can be violated in languages that permit clitic-doubling such as Greek and Spanish. That is VSO orders are permitted in languages that have a doubling configuration (the relationship between $\mathrm{V}$ and $\mathrm{S}$ is one of doubling). Italian does not have doubling of the type found in Greek, hence both arguments can remain VP-internally only when the second one is a PP, and hence it does not need to check Case. This means that V never checks the case of the subject in Italian. This help us understand why the pronominal subject 
fares better. Pronouns target a position which is outside the VP. To the extent that such patterns are possible they indicate overt subject movement to a Case checking position (based on Belletti 1999). This is shown in (21) where the pronominal subject precedes the adverb marking the vP edge:

Di questo mi informeró io bene

of this myself I will inform better

\section{V $\underline{\mathbf{S}} \mathrm{O}$ and (cl)VS\#O}

Both patters are possible in Italian and Greek. Here the one pattern contains a clitic, the other not:

a. agorase o JANIS tin efimerida

b. bought John the newspaper

Greek it bought John, the newspaper

a. Ha comprato Maria, il giornale

Italian

b. L'ha comprato Maria, il giornale

it bought Mary the newspaper

Greek permits a further pattern.

$$
\begin{aligned}
& \text { c. tin agorase o Janis tin efimerida } \\
& \text { it bought John the newspaper }
\end{aligned}
$$

It will be shown that the two patterns, the one with and the one without the clitic are different. The difference between (22c) and (22b) relates to the difference between clitic-doubling and clitic right dislocation.

\section{The syntax of VOS VOS}

VOS is a possible word order and tends to be associated with new information and contrastive focus. The question here is how can we derive these patterns, and in addition explain the restrictions found with Italian VOS. I will argue that the marginality of VOS can be understood if Italian VOS involves VP internal scrambling. 


\section{V모}

In this case the object bears contrastive focus. For Italian, Cardinaletti (2001) argues that subject is right dislocated. Indeed in cases where the object bears contrastive focus the subject has been previously mentioned, and could be analysed as being right dislocated.

\section{CIVOS}

In this case clVOS belong to the 'known' part of the clause, and the subject receives new information. This is impossible in languages that have right dislocation only. In principle the syntax of CIVOS should not be different from that of VOS, but see Revithiadou \& Spyropoulos (2002).

\section{Two word order parameters Two types of VSO languages}

There are two types of VSO languages. Both are characterized by V-movement. But they differ as to whether they make another, non EPP-related vP external specifier available for the subject DP, like non pro-drop languages. This is present in Irish, but not in Greek, Alexiadou \& Anagnostopoulou (1998).

\section{Two types of VOS languages}

There are two types of VOS languages differentiated by the XP vs. $\mathrm{X}^{\circ}$ movement parameter. The languages discussed here have been all argued to have head movement. According to Pearson (2001), Malagasy lacks head movement and rather makes use of XP movement.

\section{Pearson's generalization}

a. languages with suffixal tense/aspect morphology seem to have Verb movement, if overt.

b. language with prefixal tense/aspect morphology seem to have XP movement, if overt.

Greek instantiates pattern (a), while Malagasy instantiates pattern (b). 


\section{References}

Alexiadou, A. and Anagnostopoulou, E. 1998. Parametrizing Agr: Word Order, Verb-movement and EPP-checking. Natural Language and Linguistic Theory 16.3, 491-539.

Alexiadou, A. and Anagnostopoulou, E. 2001. The subject in situ generalization, and the role of Case in driving computations. Linguistic Inquiry 32, 193-231.

Belletti, A. 1988. The case of unaccusatives. Linguistic Inquiry 19, 1-34.

Belletti, A. 1999. VSO vs. VOS: On the licensing of possible positions for postverbal subjects in Italian and Romance. Paper presented at the workshop on Inversion, May 1998, Amsterdam.

Belletti, A. 2001. Aspects of the Low IP area. Manuscript, University of Siena.

Benincà, P. 1988. L'ordine degli elementi della frase e le costruzioni marcate: soggetto postverbale. In L. Renzi (ed.) Grande grammatica italiana di consultazione, vol. 1, 115-191. Il Mulino.

Cardinaletti, A. 1997. Subjects and Clause Structure. In L. Haegeman (ed.) The New Comparative Syntax, 33-63. London, Longman.

Cardinaletti, A. 1999. On Italian Post-verbal Subjects. Ms., University of Venice.

Cardinaletti, A. 2001. A second thought on emarginazione: destressing vs. right dislocation. In G. Cinque and G. Salvi (eds) Current studies in Italian Syntax, 118-135. Amsterdam, Elsevier.

Cardinaletti, A. 2002. Against optional and null clitics: right dislocation vs. marginalization. Studia Linguistica 56, 39-58.

Cardinaletti, A. To appear. Towards a cartography of subject positions.

Georgiafentis, M. 2001. On the properties of the VOS order in Greek. University of Reading Working Papers in Linguistics 5: 137-154.

Kayne, R. 1994. The antisymmetry of syntax. Cambridge, Mass,. MIT Press.

Pearson, M. 2001. The clause structure of Malagasy: a minimalist approach. Ph.D. dissertation, UCLA.

Pinto, M. 1997. Licensing and interpreation of inverted subjects in Italian. Doctoral dissertation, University of Utrecht.

Revithiadou, A. and Spyropoulos, V. 2002. Trapped within a phrase: effects of syntactic derivation of p-phrasing. Ms. University of the Aegean.

Tortora, C. 2001. Evidence for a null locative in Italian. In G. Cinque and G. Salvi (eds) Current studies in Italian Syntax, 313-326. Amsterdam, Elsevier.

Zubizarreta, M.L. 1998. Prosody, Focus and Word Order. Cambridge, Mass,. MIT Press. 